\title{
Interaction between the 5-HT system and the basal ganglia: functional implication and therapeutic perspective in Parkinson's disease
}

\author{
Cristina Miguelez ${ }^{1,2}$, Teresa Morera-Herreras ${ }^{1}$, Maria Torrecilla $^{1}$, Jose A. Ruiz-Ortega ${ }^{1,2}$ and \\ Luisa Ugedo ${ }^{1 *}$
}

${ }^{1}$ Department of Pharmacology, Faculty of Medicine and Dentistry, University of the Basque Country UPV/EHU, Leioa, Spain

2 Department of Pharmacology, Faculty of Pharmacy, University of the Basque Country UPV/EHU, Vitoria-Gasteiz, Spain

\section{Edited by:}

M. Victoria Puig, Massachusetts Institute of Technology, USA

\section{Reviewed by:}

Bruno Pierre Guiard, University of Paris XI, France

Karen Jaunarajs, University of Alabama, USA

Kristin Briana Dupre, National Institutes of Health, USA

\section{*Correspondence:}

Luisa Ugedo, Department of

Pharmacology, Faculty of Medicine and Dentistry, University of the

Basque Country UPV/EHU, Barrio

Sarriena sn, 48940 Leioa, Spain

e-mail: luisa.ugedo@ehu.es
The neurotransmitter serotonin $(5-\mathrm{HT})$ has a multifaceted function in the modulation of information processing through the activation of multiple receptor families, including G-protein-coupled receptor subtypes $\left(5-\mathrm{HT}_{1}, 5-\mathrm{HT}_{2}, 5-\mathrm{HT}_{4-7}\right)$ and ligand-gated ion channels $\left(5-\mathrm{HT}_{3}\right)$. The largest population of serotonergic neurons is located in the midbrain, specifically in the raphe nuclei. Although the medial and dorsal raphe nucleus (DRN) share common projecting areas, in the basal ganglia (BG) nuclei serotonergic innervations come mainly from the DRN. The BG are a highly organized network of subcortical nuclei composed of the striatum (caudate and putamen), subthalamic nucleus (STN), internal and external globus pallidus (or entopeduncular nucleus in rodents, GPi/EP and GPe) and substantia nigra (pars compacta, SNc, and pars reticulata, SNr). The BG are part of the cortico-BG-thalamic circuits, which play a role in many functions like motor control, emotion, and cognition and are critically involved in diseases such as Parkinson's disease (PD). This review provides an overview of serotonergic modulation of the BG at the functional level and a discussion of how this interaction may be relevant to treating PD and the motor complications induced by chronic treatment with L-DOPA.

Keywords: 5-HT, basal ganglia, electrophysiology, Parkinson's disease, L-DOPA induced dyskinesia

Serotonergic innervation in the brain originates from the raphe nuclei. Both, the medial and the dorsal raphe nucleus (DRN), project to common areas implicated in motor control, such as the thalamus. Nevertheless, the basal ganglia (BG) nuclei receive serotonergic afferences coming prevalently from the DRN (reviewed in Di Matteo et al., 2008). The BG contain serotonin (5-HT) and its metabolite 5-hydroxy-indolacetic acid (5-HIAA) (Palkovits et al., 1974; Saavedra, 1977; Lavoie and Parent, 1990), 5-HT transporter (SERT) and serotonergic receptors (from 5- $\mathrm{HT}_{1}$ to 5 $\mathrm{HT}_{7}$ ). These serotonergic receptors are unevenly expressed along the BG, and their distribution also differs between species. Here, we will review the evidences supporting the serotonergic system as a modulator of the BG functionality. Both physiological and pathological conditions will be analyzed from the basic and clinical point of view.

\section{PHYSIOLOGICAL SEROTONERGIC MODULATION OF THE BASAL GANGLIA}

In accordance with its neuroanatomical distribution (as summarized in Table 1), 5-HT physiologically modulates BG nuclei activity by acting on serotonergic receptors.

\section{STRIATUM}

The striatum is the main input nucleus of the BG and a key neural substrate for motor function. Several studies have shown that 5-HT affects striatal function. In fact, both DRN stimulation and local administration of 5-HT into the striatum inhibit the vast majority of the striatal cells (Olpe and Koella, 1977; Davies and Tongroach, 1978; Yakel et al., 1988). However, by performing intracellular recordings, some researchers have reported striatal excitatory postsynaptic potentials after DRN stimulation, as well as a 5-HT-induced increase in firing rate of medium spiny neurons (MSN) (Vandermaelen et al., 1979; Park et al., 1982; Stefani et al., 1990; Wilms et al., 2001). Stimulation of presynaptic $5-\mathrm{HT}_{1 \mathrm{~A}}$ and $5-\mathrm{HT}_{1 \mathrm{~B}}$ receptors inhibits striatal 5-HT release (Gerber et al., 1988; Knobelman et al., 2000), and these receptors also control the release of other neurotransmitters in the striatum. Accordingly, 5- $\mathrm{HT}_{1 \mathrm{~A}}$ receptor activation decreases glutamate release from corticostriatal projections (Antonelli et al., 2005; Mignon and Wolf, 2005; Dupre et al., 2011, 2013). On the other hand, activation of $5-\mathrm{HT}_{1 \mathrm{~B}}$ receptors indirectly stimulates the substantia nigra pars compacta (SNc) by decreasing GABA release from the substantia nigra pars reticulata $(\mathrm{SNr})$, what consequently leads to increasing striatal dopamine levels (Gerber et al., 1988).

The $5-\mathrm{HT}_{2}$ receptor family produces an inhibitory action on striatal neuron activity, mainly by modulating MSN (el Mansari et al., 1994; el Mansari and Blier, 1997). Moreover, Rueter et al. (2000) have shown that $5-\mathrm{HT}_{2} \mathrm{C}$ receptors exert tonic inhibitory control over MSN membrane excitability. Other in vivo studies, however, have shown contradictory results suggesting that the effect of serotonergic drugs depends on the area of the striatum analyzed (Wilms et al., 2001). 5- $\mathrm{HT}_{2}$ receptor activation indirectly reduces the activity of striatal MSN 
Table 1 | Localization and expression density of serotonergic receptors in the basal ganglia of healthy brains of rodents, monkeys and humans.

\begin{tabular}{|c|c|c|c|c|c|}
\hline & GPe/GPi(EP) & Striatum & STN & $\mathrm{SNc} / \mathrm{SNr}$ & References \\
\hline $5-\mathrm{HT}_{1 \mathrm{~B}}$ & $\begin{array}{l}+++^{r} \\
+++^{h}\end{array}$ & $\begin{array}{l}++^{r} \\
++^{h}\end{array}$ & $+++^{r}$ & $\begin{array}{l}+++^{r} \\
+++^{h}\end{array}$ & $\begin{array}{l}\text { 'Bruinvels et al., } 1993 \\
\text { hVarnas et al., 2004a }\end{array}$ \\
\hline $5-\mathrm{HT}_{2 \mathrm{C}}$ & $\begin{array}{l}++^{r} \\
+++^{h}\end{array}$ & $\begin{array}{l}++^{r} \\
+++^{h}\end{array}$ & $+++^{r}$ & $\begin{array}{l}+++^{r}(\mathrm{c}) \\
+++^{\mathrm{h}}\end{array}$ & 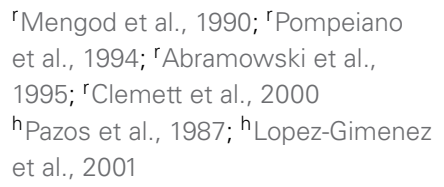 \\
\hline $5-\mathrm{HT}_{4}$ & $\begin{array}{l}+++^{r} \\
+++^{m} \\
+++^{h}\end{array}$ & $\begin{array}{l}+++^{r} \\
+++^{m} \\
+++^{h}\end{array}$ & & $\begin{array}{l}+++^{r} \\
+++^{m} \\
+++^{h}\end{array}$ & $\begin{array}{l}\text { r,m Jakeman et al., 1994; ' Nirogi et al., } \\
2013 \\
\text { hBonaventure et al., 2000; 'hVarnas } \\
\text { et al., 2003, 2004a }\end{array}$ \\
\hline $5-\mathrm{HT}_{5 \mathrm{~A}}$ & $t^{r}$ & $+^{r}$ & $++^{r}$ & $+++^{r}$ & rOliver et al., 2000 \\
\hline $5-\mathrm{HT}_{6}$ & & $\begin{array}{l}+++^{r} \\
+++^{h}\end{array}$ & & $\begin{array}{l}++^{r} \\
++^{h}\end{array}$ & $\begin{array}{l}\text { 'Gerard et al., } 1997 \\
\text { hKohen et al., } 1996\end{array}$ \\
\hline $5-\mathrm{HT}_{7}$ & $+^{r}$ & $\begin{array}{l}+^{r} \\
+^{h}\end{array}$ & $+^{\mathrm{h}}$ & $\begin{array}{l}+^{r} \\
+^{h}\end{array}$ & $\begin{array}{l}\text { rHorisawa et al., } 2013 \\
\text { r,h Martin-Cora and Pazos, } 2004 \\
\text { hVarnas et al., 2004b }\end{array}$ \\
\hline
\end{tabular}

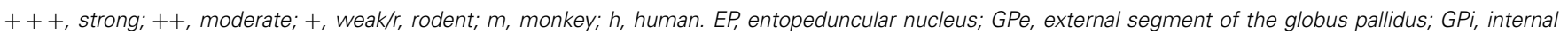
segment of the globus pallidus; STN, subthalamic nucleus; SNc, substantia nigra pars compacta; SNr, substantia nigra pars reticulata.

by enhancing the inhibitory tone of cholinergic interneurons over these output neurons. The increased release of acetylcholine is due to activation of cholinergic interneurons mainly through $5-\mathrm{HT}_{2} \mathrm{C}$ receptors, although the involvement of $5-\mathrm{HT}_{6}$ and $5-\mathrm{HT}_{7}$ receptors has also been demonstrated (Bonsi et al., 2007; Blomeley and Bracci, 2009). In addition, the activation of $5-\mathrm{HT}_{2} \mathrm{C}$ receptors located on fast-spiking interneurons increases their excitability, causing an enhancement of GABAergic postsynaptic inhibition that also decreases the activity of striatal projecting neurons (Blomeley and Bracci, 2009).

\section{SUBTHALAMIC NUCLEUS}

5-HT exerts a complex effect in the subthalamic nucleus (STN) that is considered to be a powerful excitatory drive in the BG motor circuit. Both pharmacological lesion of the DRN and 5-HT depletion increase STN firing frequency and burst activity in vivo (Liu et al., 2007; Aristieta et al., 2013). Decreased and increased excitability have been reported with the activation of $5-\mathrm{HT}_{1 \mathrm{~A}}$ and 5- $\mathrm{HT}_{2 \mathrm{C}}$, and 5- $\mathrm{HT}_{4}$ receptors, respectively (Flores et al., 1995; Stanford et al., 2005; Xiang et al., 2005; Shen et al., 2007; Aristieta et al., 2013). In addition, activation of $5-\mathrm{HT}_{1 \mathrm{~B}}$ receptors inhibits synaptic activity of STN neurons (Barwick et al., 2000; Shen and Johnson, 2008).

\section{GLOBUS PALLIDUS}

The globus pallidus (GP) has two segments, the external GP (GPe), which has a central position in the BG loop, and the internal GP (GPi/EP), which, together with the $\mathrm{SNr}$, form the output structures of the BG. In the GPe, 5-HT depletion decreases the firing frequency and increases the proportion of bursty and irregular neurons (Delaville et al., 2012b). In contrast, local application of 5-HT or selective serotonin reuptake inhibitor (SSRI) administration excites most of GPe neurons (Querejeta et al., 2005; Zhang et al., 2010; Wang et al., 2013). These findings have been further confirmed by a patch-clamp recording study in which 5-HT perfusion produced a reversible depolarization of the GP neuron membrane potential, thereby increasing the firing rate of these neurons (Chen et al., 2008). In vivo studies indicate that the stimulatory effect of 5-HT on GPe neurons is mediated by the activation of $5-\mathrm{HT}_{4}$ or $5-\mathrm{HT}_{7}$ postsynaptic receptors, but not $5-\mathrm{HT}_{2} \mathrm{C}$ and $5-\mathrm{HT}_{3}$ receptors (Bengtson et al., 2004; Kita et al., 2007; Chen et al., 2008; Hashimoto and Kita, 2008). In contrast, 5-HT can decrease the presynaptic 
release of glutamate and GABA from the subthalamopallidal and striatopallidal terminals, respectively, through $5-\mathrm{HT}_{1 \mathrm{~B}}$ receptors (Querejeta et al., 2005). In addition, 5-HT has been proposed to modulate the inhibitory and excitatory responses in GPe electrical stimulation of the motor cortex in awake monkeys (Kita et al., 2007). In fact, 5-HT suppresses GABAergic inhibitory responses to cortical stimulation through presynaptic $5-\mathrm{HT}_{1 \mathrm{~B}}$ receptors and glutamatergic excitatory responses involving presynaptic or postsynaptic $5-\mathrm{HT}_{1 \mathrm{~A}}$ receptors (Kita et al., 2007).

Few studies have been conducted to investigate the effects of 5-HT on the GPi/EP nucleus. Recently, it has been shown that intra-EP administration of a $5-\mathrm{HT}_{2}$ receptor agonist promotes oral movements and inhibits EP neuronal activity in dopamine-depleted rats (Lagiere et al., 2013).

\section{SUBSTANTIA NIGRA}

Together with the GPi, the SNr constitutes the principal output nucleus of the $\mathrm{BG}$ and plays a relevant role in movement initiation. In this nucleus, 5-HT induces mostly an inhibitory effect in vivo (Dray et al., 1976; Collingridge and Davies, 1981), while 5-HT depletion decreases firing rate and increases burst activity of SNr neurons (Delaville et al., 2012a). Electrophysiological studies carried out in brain slices indicate that 5-HT not only excites $\mathrm{SNr}$ neurons acting directly on 5-HT $2 \mathrm{C}$ receptors (Rick et al., 1995; Stanford and Lacey, 1996; Stanford et al., 2005) but also disinhibits SNr neurons by reducing GABA release from striatonigral terminals via presynaptic $5-\mathrm{HT}_{1 \mathrm{~B}}$ receptor stimulation (Stanford and Lacey, 1996). A recent electrophysiological study reveals that presynaptic $5-\mathrm{HT}_{1 \mathrm{~B}}$ receptor activation gates STN excitatory inputs to the $\mathrm{SNr}$ and reduces burst firing activity of the $\mathrm{SNr}$, and therefore may be critically involved in movement control (Ding et al., 2013).

The role of 5-HT transmission in modulating the activity of dopaminergic SNc neurons is still unclear. Although the effect of 5-HT input seems to be inhibitory (Sinton and Fallon, 1988; Arborelius et al., 1993), chemical lesion of the DRN does not significantly alter SNc activity and DRN electrical stimulation only inhibits spontaneous activity in a subset of neurons (Kelland et al., 1990). Further, SSRI administration does not modulate SNc activity (Prisco and Esposito, 1995), and 5-HT depletion has been shown to either decrease or have no significant effect on SNc neuron excitability (Kelland et al., 1990; Minabe et al., 1996). Non-selective 5- $\mathrm{HT}_{2}$ receptor antagonists stimulate SNc neurons (Ugedo et al., 1989), whereas $5-\mathrm{HT}_{4}$ receptors selectively prevents the stimulatory effect induced by haloperidol in this brain area (Lucas et al., 2001).

\section{IMPLICATION OF THE SEROTONERGIC SYSTEM IN PARKINSON'S DISEASE}

In the parkinsonian state and subsequent replacement therapy with L-DOPA, the serotonergic system adapts to the lack of dopamine by adopting anatomical and functional transformations.

\section{SEROTONERGIC SYSTEM IN PARKINSON'S DISEASE AND PARKINSONIAN ANIMAL MODELS}

Parkinson's disease (PD) is a neurodegenerative disease typified by loss of dopaminergic neurons in the SNc and subsequent dopamine depletion in the striatum. In patients with $\mathrm{PD}$, it is generally supported that serotonergic neurotransmission decreases in advanced stages of the disease (Haapaniemi et al., 2001; Kerenyi et al., 2003) since the DRN, in addition to other nuclei, undergoes degeneration (Halliday et al., 1990; Jellinger, 1990). Moreover, 5-HT and 5-HIAA concentrations, as well as SERT expression, are reduced in several BG nuclei (Scatton et al., 1983; Raisman et al., 1986; D'Amato et al., 1987; Chinaglia et al., 1993; Kerenyi et al., 2003; Guttman et al., 2007; Kish et al., 2008; Rylander et al., 2010). Regarding receptor expression, $5-\mathrm{HT}_{1 \mathrm{~A}}$ is decreased and $5-\mathrm{HT}_{2} \mathrm{C}$ is increased in some BG nuclei (Fox and Brotchie, 2000; Ballanger et al., 2012)

(Figure 1). Other serotonergic receptor $\left(5-\mathrm{HT}_{1 \mathrm{~B} / \mathrm{D}}, 5-\mathrm{HT}_{3}\right.$, and $5-\mathrm{HT}_{4}$ ) densities are however not modified by the dopaminergic loss (Steward et al., 1993; Reynolds et al., 1995; Wong et al., 1996; Castro et al., 1998). Overall, this dysfunctional serotonergic neurotransmission can indeed be linked to the high prevalence of depressive symptoms in parkinsonian patients (Reijnders et al., 2008).

In animal models of parkinsonism, the changes occurring after dopaminergic lesion have not been equally reproduced by different research groups. The discrepancies between these studies may be due to different protocol paradigms used for inducing the parkinsonian state, including the age of the animals, site of injection, concentration of the toxin, and the time between surgery and performing the studies. Several researchers have reported hyperinnervation (Zhou et al., 1991; Rozas et al., 1998; Balcioglu et al., 2003; Maeda et al., 2003), while others found no sprouting (Prinz et al., 2013), or even a decrease in striatal serotonergic fibers after dopaminergic damage (Takeuchi et al., 1991; Rylander et al., 2010). Along the same lines, striatal 5HT levels have been found to be increased (Commins et al., 1989; Zhou et al., 1991; Karstaedt et al., 1994; Balcioglu et al., 2003), unchanged (Breese et al., 1984; Carta et al., 2006), or decreased (Frechilla et al., 2001; Aguiar et al., 2006, 2008). As detailed in Figure 1, studies performed in different animal models report unequal modification in serotonergic receptor expression along the BG nuclei. On the other hand, the DRN also suffers adaptative changes after the dopaminergic degeneration, such as increased $5-\mathrm{HT}_{1 \mathrm{~A}}$ expression in MPTP monkeys (Frechilla et al., 2001) or weaker inhibitory effects of $5-\mathrm{HT}_{1 \mathrm{~A}}$ agonists on neuron activity in rats (Wang et al., 2009). Electrophysiological studies using different 6-hydroxydopamine (6-OHDA) lesion models have shown increased basal firing rate of serotonergic cells in the parkinsonian state (Zhang et al., 2007a; Kaya et al., 2008; Wang et al., 2009; Prinz et al., 2013), while others show decreases (Guiard et al., 2008) or no changes (Miguelez et al., 2011).

In spite of the disparity of results, it seems clear that to varying extents, the serotonergic system is affected in parkinsonian conditions. More clinical and preclinical studies using the same experimental models and a greater amount of samples would help to clarify the role of the serotonergic system in each stage of PD. 


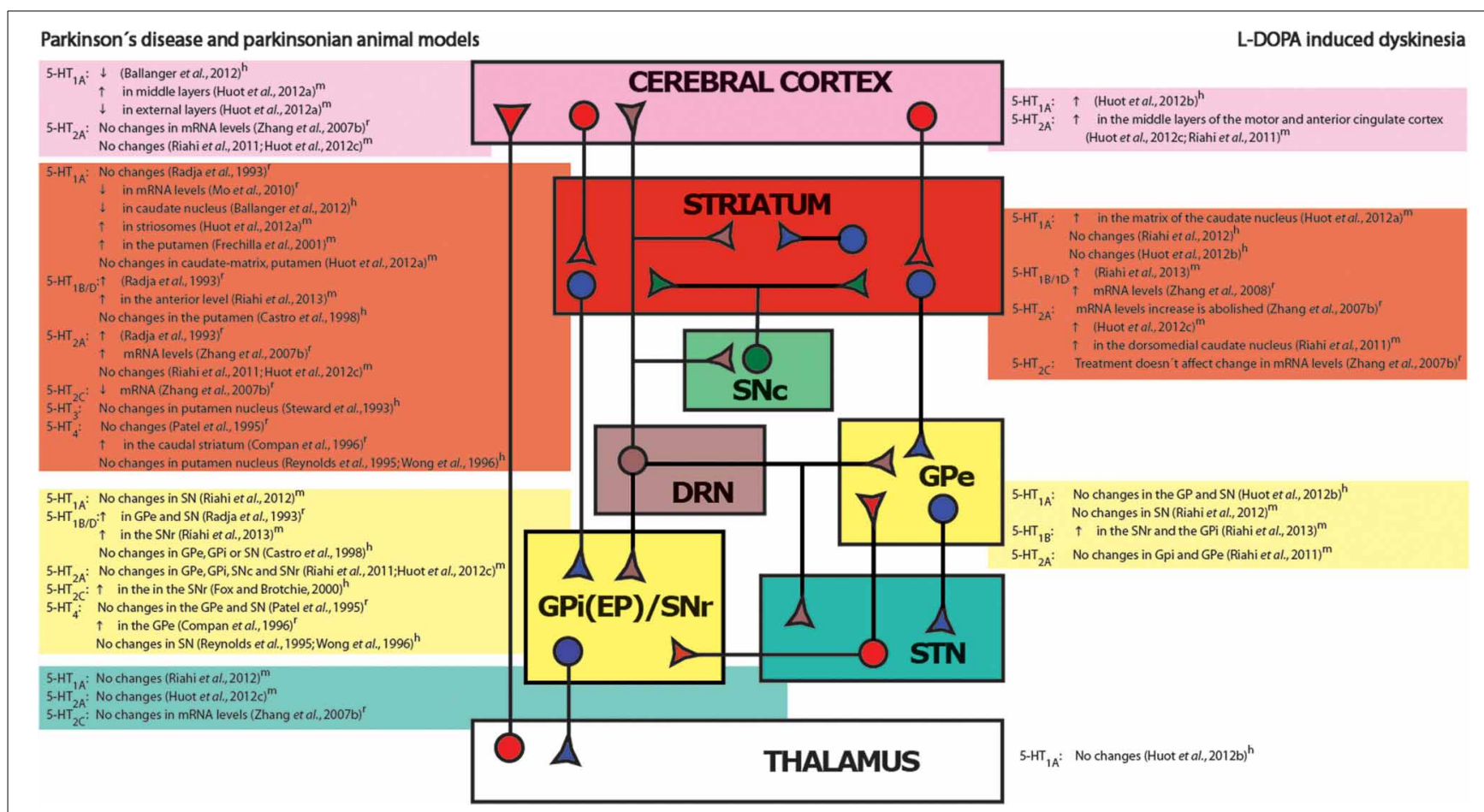

FIGURE 1 | Simplified diagram of the basal ganglia circuits and altered serotonergic receptor expression in pathological states. Changes found in serotonergic receptor density in parkinsonian (left boxes) and dyskinetic (right boxes) patients or animals models compared to control conditions. Each nucleus and its modifications in receptor expression are encoded with the same color. GABAergic inhibitory pathways are represented in dark blue and glutamatergic excitatory pathways in red. Modulatory dopaminergic connections are indicated in green and serotonergic pathways in brown. DRN, dorsal raphe nucleus; GPi (EP), internal segment of the globus pallidus (entopeduncular nucleus); GPe, external segment of the globus pallidus; STN, subthalamic nucleus; SNc, substantia nigra pars compacta; $\mathrm{SNr}$, substantia nigra pars reticulata. $r$, rodent; $m$, monkey; $h$, human.

\section{SEROTONERGIC SYSTEM IN L-DOPA INDUCED DYSKINESIA}

The dopamine precursor L-DOPA is the most effective pharmacological treatment for $\mathrm{PD}$, but it does not stop the progression of the disease. Moreover, long-term administration of L-DOPA induces motor complications, known as L-DOPA induced dyskinesias (LID), which have been related to adaptive changes of the serotonergic system. For example, a recent publication revealed that patients who had developed dyskinetic movements showed significant serotonergic hyperinnervation in the GPe and caudate, in comparison to non-dyskinetic individuals (Rylander et al., 2010). Such sprouting was directly correlated with the severity of motor complications. In contrast, other studies have shown that striatal postmortem content of 5-HT and SERT levels did not differ significantly between dyskinetic and non-dyskinetic cases (Calon et al., 2003; Kish et al., 2008), and chronic L-DOPA treatment did not influence SERT expression (Politis et al., 2010). As for serotonergic receptors, a study performed in $\mathrm{PD}$ patients that followed L-DOPA treatment showed increased 5- $\mathrm{HT}_{1 \mathrm{~A}}$ expression in several cortical areas, while no modification in the striatum, GP, SN, or thalamus was reported (Huot et al., 2012b). In the SNr, 5-HT $2 \mathrm{C}$ expression has also been observed to be raised in those patients (Fox and Brotchie, 2000).

The use of animal models has provided valuable data to better understand the physiopathological mechanisms of LID. The most used models include non-human primates injected with MPTP and rodent-models with hemilateral dopaminergic loss chronically treated with L-DOPA. Although differences may arise from the methodological protocols, such models are considered to reproduce resembling symptoms and molecular changes to those observed in PD patients and efficiently respond to antidyskinetic therapy (Iderberg et al., 2012). It is now well known that exogenously administered L-DOPA can be stored, transformed into dopamine, and released from serotonergic terminals to multiple brain regions, including the striatum, in an uncontrolled manner, producing a non-physiological stimulation of sensitized dopaminergic receptors (Arai et al., 1995; Carta et al., 2007; Yamada et al., 2007; Navailles et al., 2010b, 2013). Lesions of the DRN consistently prevent the expression of dyskinesia (Carta et al., 2007; Eskow et al., 2009) or dopamine release after an acute L-DOPA injection (Navailles et al., 2010b). This interaction between serotonergic and dopaminergic systems is reciprocal, as 5-HT levels also decrease after L-DOPA administration, and L-DOPA itself can antagonize the effect of serotonergic agents (Bartholini et al., 1968; Everett and Borcherding, 1970; Commissiong and Sedgwick, 1979; Borah and Mohanakumar, 2007; Navailles et al., 2010a; Riahi et al., 2011; Miguelez et al., 2013). In dyskinetic animals, SERT expression has been found to be up-regulated (Rylander et al., 2010), not modified (Prinz et al., 2013), or decreased (Nevalainen et al., 2011). Serotonergic receptor expression in the BG is unevenly modified with L-DOPA 
treatment: $5-\mathrm{HT}_{2 \mathrm{~A}}$ and 5- $\mathrm{HT}_{1 \mathrm{~B}}$ receptor expression is increased (Zhang et al., 2008; Riahi et al., 2011, 2013; Huot et al., 2012c), while $5-\mathrm{HT}_{1 \mathrm{~A}}$ receptor expression is increased (Huot et al., 2012a) or does not change (Riahi et al., 2012) (Figure 1). The primary modifications occurring in the serotonergic system are thought to take place at terminal levels because no changes in the number of serotonergic neurons (Rylander et al., 2010; Inden et al., 2012) or 5-HT or dopamine levels in the DRN of dyskinetic rats have been reported (Bishop et al., 2012).

\section{CLINICAL RELEVANCE}

Although motor complications appear in the majority of the patients that receive chronic treatment with L-DOPA, an effective pharmacological tool for avoiding or treating LID expression is still missing. In this sense, $5-\mathrm{HT}_{1 \mathrm{~A} / 1 \mathrm{C}}$ receptors, which are involved in the regulation of the ectopic dopamine release, are envisaged as promising targets. In 6-OHDA-lesioned rats and MPTP monkeys chronically treated with L-DOPA, $5-\mathrm{HT}_{1 \mathrm{~A} / 1 \mathrm{C}}$ receptor agonists reduce expression of LID without impairing L-DOPA improvement in motor performance (Bibbiani et al., 2001; Ba et al., 2007; Dupre et al., 2007). Furthermore, administration of the $5-\mathrm{HT}_{1 \mathrm{~A}}$ agonist, 8-OH-DPAT, also prevents L-DOPA-induced increment of extracellular dopamine (Nahimi et al., 2012). Other drugs that modulate 5-HT neurotransmission have shown efficacy over LID. Thus, a recent study has revealed that the treatment with the precursor of 5-HT, 5-hydroxytryptophan reduces the appearance of LID in L-DOPA-primed rats (Tronci et al., 2013). The 5- $\mathrm{HT}_{2 \mathrm{~A}}$ receptor inverse agonist ACP-103 reduces tremor in rodents and LID in MPTP monkeys (Vanover et al., 2008). Acute and prolonged SSRI treatment attenuates the severity and development of LID in L-DOPA-primed and naive rats without interfering with motor improvement, which may be mediated in part by $5-\mathrm{HT}_{1 \mathrm{~A}}$ receptors (Bishop et al., 2012; Conti et al., 2014). In contrast, in PD patients, while buspirone, a partial $5-\mathrm{HT}_{1 \mathrm{~A}}$ agonist, ameliorates dyskinesia (Kleedorfer et al., 1991; Bonifati et al., 1994), sarizotan, another 5- $\mathrm{HT}_{1 \mathrm{~A}}$ receptor agonist, failed to improve it compared with placebo (Goetz et al., 2008) and significantly increased off time (Goetz et al., 2007).

\section{CONCLUDING REMARKS}

The effects of 5-HT in the BG depend on the specific nucleus and its receptor distribution. 5-HT induces an inhibition of MSN in the striatum using either direct or indirect activation of serotonergic receptors, as well as in the $\mathrm{STN}$ and $\mathrm{SNr}$ in vivo. In contrast, in the GPe the overall effect of 5-HT is excitatory. In other nuclei such as the EP or SNc the net effect is still not well understood.

The serotonergic physiological modulation may be modified in pathological conditions where the BG nuclei are highly affected. Here, we provide data regarding the alteration of the serotonergic system in $\mathrm{PD}$, pointing out important discrepancies about the relationship between the serotonergic and dopaminergic systems in pathological states. In this concern, key methodological differences such as the use of different animal species and models, pharmacological treatments or stage of the disease in PD patients may explain these inconsistencies.
In summary, the serotonergic system is implicated in the modulation of the BG activity and in the etiopathology of PD and LID. However, although in preclinical studies results indicate that serotonergic drugs may be suitable for treating LID, this fact has yet to be supported by clinical trials. Accordingly, further investigation is required to determine the most suitable serotonergic target to treat these motor disturbances.

\section{ACKNOWLEDGMENTS}

This study was supported by the grants IT747-13, PI12/00613, UPV/EHU UFI11/32.

\section{REFERENCES}

Abramowski, D., Rigo, M., Duc, D., Hoyer, D., and Staufenbiel, M. (1995). Localization of the 5-hydroxytryptamine2C receptor protein in human and rat brain using specific antisera. Neuropharmacology 34, 1635-1645. doi: 10.1016/0028-3908(95)00138-7

Aguiar, L. M., Macedo, D. S., Vasconcelos, S. M., Oliveira, A. A., De Sousa, F. C., and Viana, G. S. (2008). CSC, an adenosine A(2A) receptor antagonist and MAO B inhibitor, reverses behavior, monoamine neurotransmission, and amino acid alterations in the 6-OHDA-lesioned rats. Brain Res. 1191, 192-199. doi: 10.1016/j.brainres.2007.11.051

Aguiar, L. M., Nobre, H. V. Jr., Macedo, D. S., Oliveira, A. A., Freitas, R. M., Vasconcelos, S. M., et al. (2006). Neuroprotective effects of caffeine in the model of 6-hydroxydopamine lesion in rats. Pharmacol. Biochem. Behav. 84, 415-419. doi: 10.1016/j.pbb.2006.05.027

Antonelli, T., Fuxe, K., Tomasini, M. C., Bartoszyk, G. D., Seyfried, C. A., Tanganelli, S., et al. (2005). Effects of sarizotan on the corticostriatal glutamate pathways. Synapse 58, 193-199. doi: 10.1002/syn.20195

Arai, R., Karasawa, N., Geffard, M., and Nagatsu, I. (1995). L-DOPA is converted to dopamine in serotonergic fibers of the striatum of the rat: a double-labeling immunofluorescence study. Neurosci. Lett. 195, 195-198. doi: 10.1016/03043940(95)11817-G

Arborelius, L., Chergui, K., Murase, S., Nomikos, G. G., Hook, B. B., Chouvet, G., et al. (1993). The 5-HT1A receptor selective ligands, (R)8-OH-DPAT and (S)-UH-301, differentially affect the activity of midbrain dopamine neurons. Naunyn Schmiedebergs Arch. Pharmacol. 347, 353-362. doi: 10.1007/BF00165384

Aristieta, A., Morera-Herreras, T., Ruiz-Ortega, J. A., Miguelez, C., Vidaurrazaga, I., Arrue, A., et al. (2013). Modulation of the subthalamic nucleus activity by serotonergic agents and fluoxetine administration. Psychopharmacology (Berl.). doi: 10.1007/s00213-013-3333-0. [Epub ahead of print].

Ba, M., Kong, M., Ma, G., Yang, H., Lu, G., Chen, S., et al. (2007). Cellular and behavioral effects of 5-HT1A receptor agonist $8-\mathrm{OH}-\mathrm{DPAT}$ in a rat model of levodopa-induced motor complications. Brain Res. 1127, 177-184. doi: 10.1016/j.brainres.2006.10.020

Balcioglu, A., Zhang, K., and Tarazi, F. I. (2003). Dopamine depletion abolishes apomorphine- and amphetamine-induced increases in extracellular serotonin levels in the striatum of conscious rats: a microdialysis study. Neuroscience 119, 1045-1053. doi: 10.1016/S0306-4522(03)00219-7

Ballanger, B., Klinger, H., Eche, J., Lerond, J., Vallet, A. E., Le Bars, D., et al. (2012). Role of serotonergic 1A receptor dysfunction in depression associated with Parkinson's disease. Mov. Disord. 27, 84-89. doi: 10.1002/mds.23895

Bartholini, G., Da Prada, M., and Pletscher, A. (1968). Decrease of cerebral 5-hydroxytryptamine by 3,4-dihydroxyphenylalanine after inhibition of extracerebral decarboxylase. J. Pharm. Pharmacol. 20, 228-229. doi: 10.1111/j.20427158.1968.tb09726.x

Barwick, V. S., Jones, D. H., Richter, J. T., Hicks, P. B., and Young, K. A. (2000). Subthalamic nucleus microinjections of 5-HT2 receptor antagonists suppress stereotypy in rats. Neuroreport 11, 267-270. doi: 10.1097/00001756-20000207000009

Bengtson, C. P., Lee, D. J., and Osborne, P. B. (2004). Opposing electrophysiological actions of 5-HT on noncholinergic and cholinergic neurons in the rat ventral pallidum in vitro. J. Neurophysiol. 92, 433-443. doi: 10.1152/jn.00543.2003

Bibbiani, F., Oh, J. D., and Chase, T. N. (2001). Serotonin 5-HT1A agonist improves motor complications in rodent and primate parkinsonian models. Neurology 57, 1829-1834. doi: 10.1212/WNL.57.10.1829 
Bishop, C., George, J. A., Buchta, W., Goldenberg, A. A., Mohamed, M., Dickinson, S. O., et al. (2012). Serotonin transporter inhibition attenuates l-DOPA-induced dyskinesia without compromising l-DOPA efficacy in hemi-parkinsonian rats. Eur. J. Neurosci. 36, 2839-2848. doi: 10.1111/j.1460-9568.2012.08202.x

Blomeley, C. P., and Bracci, E. (2009). Serotonin excites fast-spiking interneurons in the striatum. Eur. J. Neurosci. 29, 1604-1614. doi: 10.1111/j.14609568.2009.06725.x

Bonaventure, P., Hall, H., Gommeren, W., Cras, P., Langlois, X., Jurzak, M., et al. (2000). Mapping of serotonin 5-HT(4) receptor mRNA and ligand binding sites in the post-mortem human brain. Synapse 36, 35-46. doi: 10.1002/(SICI)10982396(200004)36:1\&lt;35::AID-SYN4\&gt;3.0.CO;2-Y

Bonifati, V., Fabrizio, E., Cipriani, R., Vanacore, N., and Meco, G. (1994). Buspirone in levodopa-induced dyskinesias. Clin. Neuropharmacol. 17, 73-82. doi: 10.1097/00002826-199402000-00008

Bonsi, P., Cuomo, D., Ding, J., Sciamanna, G., Ulrich, S., Tscherter, A., et al. (2007). Endogenous serotonin excites striatal cholinergic interneurons via the activation of 5-HT 2C, 5-HT6, and 5-HT7 serotonin receptors: implications for extrapyramidal side effects of serotonin reuptake inhibitors. Neuropsychopharmacology 32, 1840-1854. doi: 10.1038/sj.npp.1301294

Borah, A., and Mohanakumar, K. P. (2007). Long-term L-DOPA treatment causes indiscriminate increase in dopamine levels at the cost of serotonin synthesis in discrete brain regions of rats. Cell. Mol. Neurobiol. 27, 985-996. doi: 10.1007/s10571-007-9213-6

Breese, G. R., Baumeister, A. A., McCown, T. J., Emerick, S. G., Frye, G. D., Crotty, K., et al. (1984). Behavioral differences between neonatal and adult 6 hydroxydopamine-treated rats to dopamine agonists: relevance to neurological symptoms in clinical syndromes with reduced brain dopamine. J. Pharmacol. Exp. Ther. 231, 343-354.

Bruinvels, A. T., Palacios, J. M., and Hoyer, D. (1993). Autoradiographic characterisation and localisation of 5-HT1D compared to 5-HT1B binding sites in rat brain. Naunyn Schmiedebergs Arch. Pharmacol. 347, 569-582. doi: 10.1007/BF00166939

Bufton, K. E., Steward, L. J., Barber, P. C., and Barnes, N. M. (1993). Distribution and characterization of the $[3 \mathrm{H}]$ granisetron-labelled 5 -HT3 receptor in the human forebrain. Neuropharmacology 32, 1325-1331. doi: 10.1016/00283908(93)90027-Z

Calon, F., Morissette, M., Rajput, A. H., Hornykiewicz, O., Bedard, P. J., and Di Paolo, T. (2003). Changes of GABA receptors and dopamine turnover in the postmortem brains of parkinsonians with levodopa-induced motor complications. Mov. Disord. 18, 241-253. doi: 10.1002/mds.10343

Carta, M., Carlsson, T., Kirik, D., and Bjorklund, A. (2007). Dopamine released from 5-HT terminals is the cause of L-DOPA-induced dyskinesia in parkinsonian rats. Brain 130, 1819-1833. doi: 10.1093/brain/awm082

Carta, M., Lindgren, H. S., Lundblad, M., Stancampiano, R., Fadda, F., and Cenci, M. A. (2006). Role of striatal L-DOPA in the production of dyskinesia in 6-hydroxydopamine lesioned rats. J. Neurochem. 96, 1718-1727. doi: 10.1111/j.1471-4159.2006.03696.x

Castro, M. E., Pascual, J., Romon, T., Berciano, J., Figols, J., and Pazos, A. (1998). 5-HT1B receptor binding in degenerative movement disorders. Brain Res. 790, 323-328. doi: 10.1016/S0006-8993(97)01566-7

Chen, L., Yung, K. K., Chan, Y. S., and Yung, W. H. (2008). 5-HT excites globus pallidus neurons by multiple receptor mechanisms. Neuroscience 151, 439-451. doi: 10.1016/j.neuroscience.2007.11.003

Chinaglia, G., Landwehrmeyer, B., Probst, A., and Palacios, J. M. (1993). Serotoninergic terminal transporters are differentially affected in Parkinson's disease and progressive supranuclear palsy: an autoradiographic study with $[3 \mathrm{H}]$ citalopram. Neuroscience 54, 691-699. doi: 10.1016/0306-4522(93) 90240-G

Clemett, D. A., Punhani, T., Duxon, M. S., Blackburn, T. P., and Fone, K. C. (2000). Immunohistochemical localisation of the 5 -HT2C receptor protein in the rat CNS. Neuropharmacology 39, 123-132. doi: 10.1016/S0028-3908(99)00 086-6

Collingridge, G. L., and Davies, J. (1981). The influence of striatal stimulation and putative neurotransmitters on identified neurones in the rat substantia nigra. Brain Res. 212, 345-359. doi: 10.1016/0006-8993(81)90467-4

Commins, D. L., Shaughnessy, R. A., Axt, K. J., Vosmer, G., and Seiden, L. S. (1989). Variability among brain regions in the specificity of 6hydroxydopamine (6-OHDA)-induced lesions. J. Neural Transm. 77, 197-210. doi: $10.1007 / \mathrm{BF} 01248932$
Commissiong, J. W., and Sedgwick, E. M. (1979). Depletion of 5-HT by L-DOPA in spinal cord and brainstem of rat. Life Sci. 25, 83-86. doi: 10.1016/00243205(79)90493-4

Compan, V., Daszuta, A., Salin, P., Sebben, M., Bockaert, J., and Dumuis, A. (1996). Lesion study of the distribution of serotonin 5-HT4 receptors in rat basal ganglia and hippocampus. Eur. J. Neurosci. 8, 2591-2598. doi: 10.1111/j.14609568.1996.tb01553.x

Conti, M. M., Ostock, C. Y., Lindenbach, D., Goldenberg, A. A., Kampton, E., Dell'isola, R., et al. (2014). Effects of prolonged selective serotonin reuptake inhibition on the development and expression of 1-DOPA-induced dyskinesia in hemi-parkinsonian rats. Neuropharmacology 77, 1-8. doi: 10.1016/j.neuropharm.2013.09.017

D’Amato, R. J., Zweig, R. M., Whitehouse, P. J., Wenk, G. L., Singer, H. S., Mayeux, R., et al. (1987). Aminergic systems in Alzheimer's disease and Parkinson's disease. Ann. Neurol. 22, 229-236. doi: 10.1002/ana.410220207

Davies, J., and Tongroach, P. (1978). Neuropharmacological studies on the nigrostriatal and raphe-striatal system in the rat. Eur. J. Pharmacol. 51, 91-100. doi: 10.1016/0014-2999(78)90333-3

Delaville, C., Chetrit, J., Abdallah, K., Morin, S., Cardoit, L., De Deurwaerdere, P., et al. (2012a). Emerging dysfunctions consequent to combined monoaminergic depletions in Parkinsonism. Neurobiol. Dis. 45, 763-773. doi: 10.1016/j.nbd.2011.10.023

Delaville, C., Navailles, S., and Benazzouz, A. (2012b). Effects of noradrenaline and serotonin depletions on the neuronal activity of globus pallidus and substantia nigra pars reticulata in experimental parkinsonism. Neuroscience 202, 424-433. doi: 10.1016/j.neuroscience.2011.11.024

Di Matteo, V., Pierucci, M., Esposito, E., Crescimanno, G., Benigno, A., and Di Giovanni, G. (2008). Serotonin modulation of the basal ganglia circuitry: therapeutic implication for Parkinson's disease and other motor disorders. Prog. Brain Res. 172, 423-463. doi: 10.1016/S0079-6123(08)00921-7

Ding, S., Li, L., and Zhou, F. M. (2013). Presynaptic serotonergic gating of the subthalamonigral glutamatergic projection. J. Neurosci. 33, 4875-4885. doi: 10.1523/JNEUROSCI.4111-12.2013

Dray, A., Gonye, T. J., and Oakley, N. R. (1976). Caudate stimulation and substantia nigra activity in the rat. J. Physiol. 259, 825-849.

Dupre, K. B., Eskow, K. L., Negron, G., and Bishop, C. (2007). The differential effects of 5-HT(1A) receptor stimulation on dopamine receptor-mediated abnormal involuntary movements and rotations in the primed hemiparkinsonian rat. Brain Res. 1158, 135-143. doi: 10.1016/j.brainres.2007.05.005

Dupre, K. B., Ostock, C. Y., Eskow Jaunarajs, K. L., Button, T., Savage, L. M., et al. (2011). Local modulation of striatal glutamate efflux by serotonin 1A receptor stimulation in dyskinetic, hemiparkinsonian rats. Exp. Neurol. 229, 288-299. doi: 10.1016/j.expneurol.2011.02.012

Dupre, K. B., Ostock, C. Y., George, J. A., Eskow Jaunarajs, K. L., Hueston, C. M., and Bishop, C. (2013). Effects of 5-HT1A receptor stimulation on D1 receptor agonist-induced striatonigral activity and dyskinesia in hemiparkinsonian rats. ACS Chem. Neurosci. 4, 747-760. doi: 10.1021/cn300234z

el Mansari, M., and Blier, P. (1997). In vivo electrophysiological characterization of 5-HT receptors in the guinea pig head of caudate nucleus and orbitofrontal cortex. Neuropharmacology 36, 577-588. doi: 10.1016/S0028-3908(97)00035-X

el Mansari, M., Radja, F., Ferron, A., Reader, T. A., Molina-Holgado, E., and Descarries, L. (1994). Hypersensitivity to serotonin and its agonists in serotonin-hyperinnervated neostriatum after neonatal dopamine denervation. Eur. J. Pharmacol. 261, 171-178. doi: 10.1016/0014-2999(94)90316-6

Eskow, K. L., Dupre, K. B., Barnum, C. J., Dickinson, S. O., Park, J. Y., and Bishop, C. (2009). The role of the dorsal raphe nucleus in the development, expression, and treatment of L-dopa-induced dyskinesia in hemiparkinsonian rats. Synapse 63, 610-620. doi: 10.1002/syn.20630

Everett, G. M., and Borcherding, J. W. (1970). L-DOPA: effect on concentrations of dopamine, norepinephrine, and serotonin in brains of mice. Science 168, 847-850. doi: 10.1126/science.168.3933.849

Flores, G., Rosales, M. G., Hernandez, S., Sierra, A., and Aceves, J. (1995). 5-Hydroxytryptamine increases spontaneous activity of subthalamic neurons in the rat. Neurosci. Lett. 192, 17-20. doi: 10.1016/0304-3940(95) 11597-P

Fox, S. H., and Brotchie, J. M. (2000). 5-HT2C receptor binding is increased in the substantia nigra pars reticulata in Parkinson's disease. Mov. Disord. 15, 1064-1069. doi: 10.1002/1531-8257(200011)15:6\%3C1064::AIDMDS1002\%3E3.0.CO;2-C 
Frechilla, D., Cobreros, A., Saldise, L., Moratalla, R., Insausti, R., Luquin, M., et al. (2001). Serotonin 5-HT(1A) receptor expression is selectively enhanced in the striosomal compartment of chronic parkinsonian monkeys. Synapse 39, 288-296. doi: 10.1002/1098-2396(20010315)39:4\&lt;288::AIDSYN1011\&gt;3.0.CO;2-V

Gehlert, D. R., Schober, D. A., Gackenheimer, S. L., Mais, D. E., Ladouceur, G., and Robertson, D. W. (1993). Synthesis and evaluation of [125I]-(S)-iodozacopride, a high affinity radioligand for $5 \mathrm{HT} 3$ receptors. Neurochem. Int. 23, 373-383. doi: 10.1016/0197-0186(93)90081-F

Gerard, C., Martres, M. P., Lefevre, K., Miquel, M. C., Verge, D., Lanfumey, L., et al. (1997). Immuno-localization of serotonin 5-HT6 receptor-like material in the rat central nervous system. Brain Res. 746, 207-219. doi: 10.1016/S00068993(96)01224-3

Gerber, R., Altar, C. A., and Liebman, J. M. (1988). Rotational behavior induced by 8-hydroxy-DPAT, a putative 5HT-1A agonist, in 6-hydroxydopamine-lesioned rats. Psychopharmacology (Berl) 94, 178-182. doi: 10.1007/BF00176841

Goetz, C. G., Damier, P., Hicking, C., Laska, E., Müller, T., Olanow, C. W., et al. (2007). Sarizotan as a treatment for dyskinesias in Parkinson's disease: double-blind placebo-controlled trial. Mov. Disord. 22, 179-186. doi: $10.1002 / \mathrm{mds} .21226$

Goetz, C. G., Laska, E., Hicking, C., Damier, P., Muller, T., Nutt, J., et al. (2008). Placebo influences on dyskinesia in Parkinson's disease. Mov. Disord. 23, 700-707. doi: 10.1002/mds.21897

Guiard, B. P., el Mansari, M., Merali, Z., and Blier, P. (2008). Functional interactions between dopamine, serotonin and norepinephrine neurons: an invivo electrophysiological study in rats with monoaminergic lesions. Int. J. Neuropsychopharmacol. 11, 625-639. doi: 10.1017/S1461145707008383

Guttman, M., Boileau, I., Warsh, J., Saint-Cyr, J. A., Ginovart, N., Mccluskey, T., et al. (2007). Brain serotonin transporter binding in non-depressed patients with Parkinson's disease. Eur. J. Neurol. 14, 523-528. doi: 10.1111/j.14681331.2007.01727.x

Haapaniemi, T. H., Ahonen, A., Torniainen, P., Sotaniemi, K. A., and Myllyla, V. V. (2001). [123I]beta-CIT SPECT demonstrates decreased brain dopamine and serotonin transporter levels in untreated parkinsonian patients. Mov. Disord. 16, 124-130. doi: 10.1002/1531-8257(200101)16:1<124::AID-MDS1007>3.0. $\mathrm{CO} ; 2-\mathrm{R}$

Hall, H., Farde, L., Halldin, C., Lundkvist, C., and Sedvall, G. (2000). Autoradiographic localization of 5-HT(2A) receptors in the human brain using [(3)H]M100907 and [(11)C]M100907. Synapse 38, 421-431. doi: 10.1002/10982396(20001215)38:4<421::AID-SYN7>3.0.CO;2-X

Halliday, G. M., Blumbergs, P. C., Cotton, R. G., Blessing, W. W., and Geffen, L. B. (1990). Loss of brainstem serotonin- and substance P-containing neurons in Parkinson's disease. Brain Res. 510, 104-107. doi: 10.1016/0006-8993(90) 90733-R

Hashimoto, K., and Kita, H. (2008). Serotonin activates presynaptic and postsynaptic receptors in rat globus pallidus. J. Neurophysiol. 99, 1723-1732. doi: 10.1152/jn.01143.2007

Horisawa, T., Ishiyama, T., Ono, M., Ishibashi, T., and Taiji, M. (2013). Binding of lurasidone, a novel antipsychotic, to rat 5-HT7 receptor: analysis by [3H]SB269970 autoradiography. Prog. Neuropsychopharmacol. Biol. Psychiatry 40, 132-137. doi: 10.1016/j.pnpbp.2012.08.005

Hoyer, D., Pazos, A., Probst, A., and Palacios, J. M. (1986). Serotonin receptors in the human brain. II. Characterization and autoradiographic localization of 5HT1C and 5-HT2 recognition sites. Brain Res. 376, 97-107. doi: 10.1016/00068993(86)90903-0

Huot, P., Johnston, T. H., Koprich, J. B., Winkelmolen, L., Fox, S. H., and Brotchie, J. M. (2012a). Regulation of cortical and striatal 5-HT1A receptors in the MPTP-lesioned macaque. Neurobiol. Aging 33, 207.e9-e19. doi: 10.1016/j.neurobiolaging.2010.09.011

Huot, P., Johnston, T. H., Visanji, N. P., Darr, T., Pires, D., Hazrati, L. N., et al. (2012b). Increased levels of 5-HT1A receptor binding in ventral visual pathways in Parkinson's disease. Mov. Disord. 27, 735-742. doi: 10.1002/mds. 24964

Huot, P., Johnston, T. H., Winkelmolen, L., Fox, S. H., and Brotchie, J. M. (2012c). 5-HT2A receptor levels increase in MPTP-lesioned macaques treated chronically with L-DOPA. Neurobiol. Aging 33, 194.e5-e15. doi: 10.1016/j.neurobiolaging.2010.04.035

Iderberg, H., Francardo, V., and Pioli, E. Y. (2012). Animal models of L-DOPAinduced dyskinesia: an update on the current options. Neuroscience 211, 13-27. doi: 10.1016/j.neuroscience.2012.03.023
Inden, M., Abe, M., Minamino, H., Takata, K., Yoshimoto, K., Tooyama, I., et al. (2012). Effect of selective serotonin reuptake inhibitors via 5-HT1A receptors on L-DOPA-induced rotational behavior in a hemiparkinsonian rat model. J. Pharmacol. Sci. 119, 10-19. doi: 10.1254/jphs.12003FP

Jakeman, L. B., To, Z. P., Eglen, R. M., Wong, E. H., and Bonhaus, D. W. (1994). Quantitative autoradiography of 5-HT4 receptors in brains of three species using two structurally distinct radioligands, [3H]GR113808 and [3H]BIMU-1. Neuropharmacology 33, 1027-1038. doi: 10.1016/0028-3908(94)90162-7

Jellinger, K. (1990). New developments in the pathology of Parkinson's disease. $A d v$. Neurol. 53, 1-16.

Karstaedt, P. J., Kerasidis, H., Pincus, J. H., Meloni, R., Graham, J., and Gale, K. (1994). Unilateral destruction of dopamine pathways increases ipsilateral striatal serotonin turnover in rats. Exp. Neurol. 126, 25-30. doi: 10.1006/exnr.1994.1039

Kaya, A. H., Vlamings, R., Tan, S., Lim, L. W., Magill, P. J., Steinbusch, H. W., et al. (2008). Increased electrical and metabolic activity in the dorsal raphe nucleus of Parkinsonian rats. Brain Res. 1221, 93-97. doi: 10.1016/j.brainres.2008.05.019

Kelland, M. D., Freeman, A. S., and Chiodo, L. A. (1990). Serotonergic afferent regulation of the basic physiology and pharmacological responsiveness of nigrostriatal dopamine neurons. J. Pharmacol. Exp. Ther. 253, 803-811.

Kerenyi, L., Ricaurte, G. A., Schretlen, D. J., McCann, U., Varga, J., Mathews, W. B., et al. (2003). Positron emission tomography of striatal serotonin transporters in Parkinson disease. Arch. Neurol. 60, 1223-1229. doi: 10.1001/archneur.60.9.1223

Kilpatrick, G. J., Jones, B. J., and Tyers, M. B. (1987). Identification and distribution of 5-HT3 receptors in rat brain using radioligand binding. Nature 330, 746-748. doi: $10.1038 / 330746 \mathrm{a} 0$

Kish, S. J., Tong, J., Hornykiewicz, O., Rajput, A., Chang, L. J., Guttman, M., et al. (2008). Preferential loss of serotonin markers in caudate versus putamen in Parkinson's disease. Brain 131, 120-131. doi: 10.1093/brain/awm239

Kita, H., Chiken, S., Tachibana, Y., and Nambu, A. (2007). Serotonin modulates pallidal neuronal activity in the awake monkey. J. Neurosci. 27, 75-83. doi: 10.1523/JNEUROSCI.4058-06.2007

Kleedorfer, B., Lees, A. J., and Stern, G. M. (1991). Buspirone in the treatment of levodopa induced dyskinesias. J. Neurol. Neurosurg. Psychiatry 54, 376-377. doi: 10.1136/jnnp.54.4.376-a

Knobelman, D. A., Kung, H. F., and Lucki, I. (2000). Regulation of extracellular concentrations of 5-hydroxytryptamine (5-HT) in mouse striatum by 5-HT(1A) and 5-HT(1B) receptors. J. Pharmacol. Exp. Ther. 292, 1111-1117.

Kohen, R., Metcalf, M. A., Khan, N., Druck, T., Huebner, K., Lachowicz, J. E., et al. (1996). Cloning, characterization, and chromosomal localization of a human 5-HT6 serotonin receptor. J. Neurochem. 66, 47-56. doi: 10.1046/j.14714159.1996.66010047.x

Lagiere, M., Navailles, S., Mignon, L., Roumegous, A., Chesselet, M. F., and Deurwaerdere, P. D. (2013). The enhanced oral response to the $5-\mathrm{HT}_{2}$ agonist Ro 60-0175 in parkinsonian rats involves the entopeduncular nuclues: electrophysiological correlates. Exp. Brain Res. 230, 513-524. doi: 10.1007/s00221-0133478-4

Lanfumey, L., and Hamon, M. (2000). Central 5-HT(1A) receptors: regional distribution and functional characteristics. Nucl. Med. Biol. 27, 429-435. doi: 10.1016/S0969-8051(00)00107-4

Lavoie, B., and Parent, A. (1990). Immunohistochemical study of the serotoninergic innervation of the basal ganglia in the squirrel monkey. J. Comp. Neurol. 299, 1-16. doi: 10.1002/cne.902990102

Liu, J., Chu, Y. X., Zhang, Q. J., Wang, S., Feng, J., and Li, Q. (2007). 5,7dihydroxytryptamine lesion of the dorsal raphe nucleus alters neuronal activity of the subthalamic nucleus in normal and 6-hydroxydopamine-lesioned rats. Brain Res. 1149, 216-222. doi: 10.1016/j.brainres.2007.02.052

Lopez-Gimenez, J. F., Mengod, G., Palacios, J. M., and Vilaro, M. T. (2001). Regional distribution and cellular localization of 5-HT2C receptor mRNA in monkey brain: comparison with $[3 \mathrm{H}]$ mesulergine binding sites and choline acetyltransferase mRNA. Synapse 42, 12-26. doi: 10.1002/syn.1095

Lucas, G., Di Matteo, V., De Deurwaerdere, P., Porras, G., Martin-Ruiz, R., Artigas, F., et al. (2001). Neurochemical and electrophysiological evidence that 5-HT4 receptors exert a state-dependent facilitatory control in vivo on nigrostriatal, but not mesoaccumbal, dopaminergic function. Eur. J. Neurosci. 13, 889-898. doi: 10.1046/j.0953-816x.2000.01453.x

Maeda, T., Kannari, K., Shen, H., Arai, A., Tomiyama, M., Matsunaga, M., et al. (2003). Rapid induction of serotonergic hyperinnervation in the adult rat 
striatum with extensive dopaminergic denervation. Neurosci. Lett. 343, 17-20. doi: $10.1016 / \mathrm{S} 0304-3940(03) 00295-7$

Martin-Cora, F. J., and Pazos, A. (2004). Autoradiographic distribution of 5HT7 receptors in the human brain using $[3 \mathrm{H}]$ mesulergine: comparison to other mammalian species. Br. J. Pharmacol. 141, 92-104. doi: 10.1038/sj.bjp.07 05576

Mengod, G., Pompeiano, M., Martinez-Mir, M. I., and Palacios, J. M. (1990). Localization of the mRNA for the 5-HT2 receptor by in situ hybridization histochemistry. Correlation with the distribution of receptor sites. Brain Res. 524, 139-143. doi: 10.1016/0006-8993(90)90502-3

Mignon, L. J., and Wolf, W. A. (2005). 8-hydroxy-2-(di-n-propylamino)tetralin reduces striatal glutamate in an animal model of Parkinson's disease. Neuroreport 16, 699-703. doi: 10.1097/00001756-200505120-00009

Miguelez, C., Berrocoso, E., Mico, J. A., and Ugedo, L. (2013). 1-DOPA modifies the antidepressant-like effects of reboxetine and fluoxetine in rats. Neuropharmacology 67, 349-358. doi: 10.1016/j.neuropharm.2012.11.016

Miguelez, C., Grandoso, L., and Ugedo, L. (2011). Locus coeruleus and dorsal raphe neuron activity and response to acute antidepressant administration in a rat model of Parkinson's disease. Int. J. Neuropsychopharmacol. 14, 187-200. doi: 10.1017/S146114571000043X

Minabe, Y., Emori, K., and Ashby, C. R. Jr. (1996). The depletion of brain serotonin levels by para-chlorophenylalanine administration significantly alters the activity of midbrain dopamine cells in rats: an extracellular single cell recording study. Synapse 22, 46-53. doi: 10.1002/(SICI)10982396(199601)22:1\%3C46::AID-SYN5\%3E3.3.CO;2-I

Mo, J., Zhang, H., Yu, L. P., Sun, P. H., Jin, G. Z., and Zhen, X. (2010). L-stepholidine reduced L-DOPA-induced dyskinesia in 6-OHDA-lesioned rat model of Parkinson's disease. Neurobiol. Aging 31, 926-936. doi: 10.1016/j.neurobiolaging.2008.06.017

Nahimi, A., Holtzermann, M., Landau, A. M., Simonsen, M., Jakobsen, S., Alstrup, A. K., et al. (2012). Serotonergic modulation of receptor occupancy in rats treated with L-DOPA after unilateral 6-OHDA lesioning. J. Neurochem. 120, 806-817. doi: 10.1111/j.1471-4159.2011.07598.x

Navailles, S., Benazzouz, A., Bioulac, B., Gross, C., and De Deurwaerdere, P. (2010a). High-frequency stimulation of the subthalamic nucleus and L-3,4dihydroxyphenylalanine inhibit in vivo serotonin release in the prefrontal cortex and hippocampus in a rat model of Parkinson's disease. J. Neurosci. 30, 2356-2364. doi: 10.1523/JNEUROSCI.5031-09.2010

Navailles, S., Bioulac, B., Gross, C., and De Deurwaerdere, P. (2010b). Serotonergic neurons mediate ectopic release of dopamine induced by LDOPA in a rat model of Parkinson's disease. Neurobiol. Dis. 38, 136-143. doi: 10.1016/j.nbd.2010.01.012

Navailles, S., Lagiere, M., Contini, A., and De Deurwaerdere, P. (2013). Multisite intracerebral microdialysis to study the mechanism of L-DOPA induced dopamine and serotonin release in the parkinsonian brain. ACS Chem. Neurosci. 4, 680-692. doi: 10.1021/cn400046e

Nevalainen, N., Af Bjerken, S., Lundblad, M., Gerhardt, G. A., and Stromberg, I. (2011). Dopamine release from serotonergic nerve fibers is reduced in L-DOPA-induced dyskinesia. J. Neurochem. 118, 12-23. doi: 10.1111/j.14714159.2011.07292.x

Nirogi, R., Kandikere, V., Bhyrapuneni, G., Saralaya, R., Ajjala, D. R., Aleti, R. R., et al. (2013). In-vivo rat striatal 5-HT4 receptor occupancy using non-radiolabelled SB207145. J. Pharm. Pharmacol. 65, 704-712. doi: 10.1111/jphp. 12030

Oliver, K. R., Kinsey, A. M., Wainwright, A., and Sirinathsinghji, D. J. (2000). Localization of 5 -ht $(5 \mathrm{~A})$ receptor-like immunoreactivity in the rat brain. Brain Res. 867, 131-142. doi: 10.1016/S0006-8993(00)02273-3

Olpe, H. R., and Koella, W. P. (1977). The response of striatal cells upon stimulation of the dorsal and median raphe nuclei. Brain Res. 122, 357-360. doi: 10.1016/0006-8993(77)90302-X

Palkovits, M., Brownstein, M., and Saavedra, J. M. (1974). Serotonin content of the brain stem nuclei in the rat. Brain Res. 80, 237-249. doi: 10.1016/00068993(74)90688-X

Park, M. R., Gonzales-Vegas, J. A., and Kitai, S. T. (1982). Serotonergic excitation from dorsal raphe stimulation recorded intracellularly from rat caudateputamen. Brain Res. 243, 49-58. doi: 10.1016/0006-8993(82)91119-2

Pazos, A., Cortes, R., and Palacios, J. M. (1985). Quantitative autoradiographic mapping of serotonin receptors in the rat brain. II. Serotonin-2 receptors. Brain Res. 346, 231-249. doi: 10.1016/0006-8993(85)90857-1
Pazos, A., Probst, A., and Palacios, J. M. (1987). Serotonin receptors in the human brain-IV. Autoradiographic mapping of serotonin-2 receptors. Neuroscience 21, 123-139. doi: 10.1016/0306-4522(87)90327-7

Politis, M., Wu, K., Loane, C., Kiferle, L., Molloy, S., Brooks, D. J., et al. (2010). Staging of serotonergic dysfunction in Parkinson's disease: an in vivo 11C-DASB PET study. Neurobiol. Dis. 40, 216-221. doi: 10.1016/j.nbd.2010. 05.028

Pompeiano, M., Palacios, J. M., and Mengod, G. (1994). Distribution of the serotonin 5-HT2 receptor family mRNAs: comparison between 5-HT2A and 5-HT2C receptors. Brain Res. Mol. Brain Res. 23, 163-178. doi: 10.1016/0169328X(94)90223-2

Prinz, A., Selesnew, L. M., Liss, B., Roeper, J., and Carlsson, T. (2013). Increased excitability in serotonin neurons in the dorsal raphe nucleus in the 6OHDA mouse model of Parkinson's disease. Exp. Neurol. 248C, 236-245. doi: 10.1016/j.expneurol.2013.06.015

Prisco, S., and Esposito, E. (1995). Differential effects of acute and chronic fluoxetine administration on the spontaneous activity of dopaminergic neurones in the ventral tegmental area. Br. J. Pharmacol. 116, 1923-1931. doi: 10.1111/j.1476-5381.1995.tb16684.x

Querejeta, E., Oviedo-Chavez, A., Araujo-Alvarez, J. M., Quinones-Cardenas, A. R., and Delgado, A. (2005). In vivo effects of local activation and blockade of 5 HT1B receptors on globus pallidus neuronal spiking. Brain Res. 1043, 186-194. doi: 10.1016/j.brainres.2005.02.055

Radja, F., Descarries, L., Dewar, K. M., and Reader, T. A. (1993). Serotonin 5-HT1 and 5-HT2 receptors in adult rat brain after neonatal destruction of nigrostriatal dopamine neurons: a quantitative autoradiographic study. Brain Res. 606, 273-285. doi: 10.1016/0006-8993(93)90995-Y

Raisman, R., Cash, R., and Agid, Y. (1986). Parkinson's disease: decreased density of 3H-imipramine and 3H-paroxetine binding sites in putamen. Neurology 36, 556-560. doi: 10.1212/WNL.36.4.556

Reijnders, J. S., Ehrt, U., Weber, W. E., Aarsland, D., and Leentjens, A. F. (2008). A systematic review of prevalence studies of depression in Parkinson's disease. Mov. Disord. 23, 183-189. doi: 10.1002/mds.21803

Reynolds, G. P., Mason, S. L., Meldrum, A., De Keczer, S., Parnes, H., Eglen, R. M., et al. (1995). 5-Hydroxytryptamine (5-HT)4 receptors in post mortem human brain tissue: distribution, pharmacology and effects of neurodegenerative diseases. Br. J. Pharmacol. 114, 993-998. doi: 10.1111/j.1476-5381.1995.tb13303.x

Riahi, G., Morissette, M., Levesque, D., Rouillard, C., Samadi, P., Parent, M., et al. (2012). Effect of chronic 1-DOPA treatment on 5-HT(1A) receptors in parkinsonian monkey brain. Neurochem. Int. 61, 1160-1171. doi 10.1016/j.neuint.2012.08.009

Riahi, G., Morissette, M., Parent, M., and Di Paolo, T. (2011). Brain 5-HT(2A) receptors in MPTP monkeys and levodopa-induced dyskinesias. Eur. J. Neurosci. 33, 1823-1831. doi: 10.1111/j.1460-9568.2011.07675.x

Riahi, G., Morissette, M., Samadi, P., Parent, M., and Di Paolo, T. (2013). Basal ganglia serotonin 1B receptors in parkinsonian monkeys with L-DOPAinduced dyskinesia. Biochem. Pharmacol. 86, 970-978. doi: 10.1016/j.bcp.2013. 08.005

Rick, C. E., Stanford, I. M., and Lacey, M. G. (1995). Excitation of rat substantia nigra pars reticulata neurons by 5-hydroxytryptamine in vitro: evidence for a direct action mediated by 5 -hydroxytryptamine2C receptors. Neuroscience 69 , 903-913. doi: 10.1016/0306-4522(95)00283-O

Rozas, G., Liste, I., Guerra, M. J., and Labandeira-Garcia, J. L. (1998). Sprouting of the serotonergic afferents into striatum after selective lesion of the dopaminergic system by MPTP in adult mice. Neurosci. Lett. 245, 151-154. doi: 10.1016/S0304-3940(98)00198-0

Rueter, L. E., Tecott, L. H., and Blier, P. (2000). In vivo electrophysiological examination of 5-HT2 responses in 5-HT2C receptor mutant mice. Naunyn Schmiedebergs Arch. Pharmacol. 361, 484-491. doi: 10.1007/s0021099 00181

Rylander, D., Parent, M., O’Sullivan, S. S., Dovero, S., Lees, A. J., Bezard, E., et al. (2010). Maladaptive plasticity of serotonin axon terminals in levodopa-induced dyskinesia. Ann. Neurol. 68, 619-628. doi: 10.1002/ana.22097

Saavedra, J. M. (1977). Distribution of serotonin and synthesizing enzymes in discrete areas of the brain. Fed. Proc. 36, 2134-2141.

Scatton, B., Javoy-Agid, F., Rouquier, L., Dubois, B., and Agid, Y. (1983). Reduction of cortical dopamine, noradrenaline, serotonin and their metabolites in Parkinson's disease. Brain Res. 275, 321-328. doi: 10.1016/0006-8993(83)90 993-9 
Shen, K. Z., and Johnson, S. W. (2008). 5-HT inhibits synaptic transmission in rat subthalamic nucleus neurons in vitro. Neuroscience 151, 1029-1033. doi: 10.1016/j.neuroscience.2007.12.001

Shen, K. Z., Kozell, L. B., and Johnson, S. W. (2007). Multiple conductances are modulated by 5 -HT receptor subtypes in rat subthalamic nucleus neurons. Neuroscience 148, 996-1003. doi: 10.1016/j.neuroscience.2007.07.012

Sinton, C. M., and Fallon, S. L. (1988). Electrophysiological evidence for a functional differentiation between subtypes of the 5-HT1 receptor. Eur. J. Pharmacol. 157, 173-181. doi: 10.1016/0014-2999(88)90380-9

Stanford, I. M., Kantaria, M. A., Chahal, H. S., Loucif, K. C., and Wilson, C. L. (2005). 5-Hydroxytryptamine induced excitation and inhibition in the subthalamic nucleus: action at 5-HT(2C), 5-HT(4) and 5-HT(1A) receptors. Neuropharmacology 49, 1228-1234. doi: 10.1016/j.neuropharm.2005.09.003

Stanford, I. M., and Lacey, M. G. (1996). Differential actions of serotonin, mediated by 5 -HT1B and 5 -HT2C receptors, on GABA-mediated synaptic input to rat substantia nigra pars reticulata neurons in vitro. J. Neurosci. 16, 7566-7573.

Stefani, A., Surmeier, D. J., and Kitai, S. T. (1990). Serotonin enhances excitability in neostriatal neurons by reducing voltage-dependent potassium currents. Brain Res. 529, 354-357. doi: 10.1016/0006-8993(90)90851-2

Steward, L. J., Bufton, K. E., Hopkins, P. C., Davies, W. E., and Barnes, N. M. (1993). Reduced levels of 5-HT3 receptor recognition sites in the putamen of patients with Huntington's disease. Eur. J. Pharmacol. 242, 137-143. doi: 10.1016/00142999(93)90073-Q

Takeuchi, Y., Sawada, T., Blunt, S., Jenner, P., and Marsden, C. D. (1991). Effects of 6-hydroxydopamine lesions of the nigrostriatal pathway on striatal serotonin innervation in adult rats. Brain Res. 562, 301-305. doi: 10.1016/00068993(91)90635-9

Tronci, E., Lisci, C., Stancampiano, R., Fidalgo, C., Collu, M., Devoto, P., et al. (2013). 5-Hydroxy-tryptophan for the treatment of L-DOPA-induced dyskinesia in the rat Parkinson's disease model. Neurobiol. Dis. 60, 108-114. doi: 10.1016/j.nbd.2013.08.014

Ugedo, L., Grenhoff, J., and Svensson, T. H. (1989). Ritanserin, a 5-HT2 receptor antagonist, activates midbrain dopamine neurons by blocking serotonergic inhibition. Psychopharmacology (Berl) 98, 45-50. doi: 10.1007/BF00442004

Vandermaelen, C. P., Bonduki, A. C., and Kitai, S. T. (1979). Excitation of caudateputamen neurons following stimulation of the dorsal raphe nucleus in the rat. Brain Res. 175, 356-361. doi: 10.1016/0006-8993(79)91016-3

Vanover, K. E., Betz, A. J., Weber, S. M., Bibbiani, F., Kielaite, A., Weiner, D. M., et al. (2008). A 5-HT2A receptor inverse agonist, ACP-103, reduces tremor in a rat model and levodopa-induced dyskinesias in a monkey model. Pharmacol. Biochem. Behav. 90, 540-544. doi: 10.1016/j.pbb.2008.04.010

Varnas, K., Halldin, C., and Hall, H. (2004a). Autoradiographic distribution of serotonin transporters and receptor subtypes in human brain. Hum. Brain Mapp. 22, 246-260. doi: 10.1002/hbm.20035

Varnas, K., Thomas, D. R., Tupala, E., Tiihonen, J., and Hall, H. (2004b). Distribution of 5-HT7 receptors in the human brain: a preliminary autoradiographic study using [3H]SB-269970. Neurosci. Lett. 367, 313-316. doi: 10.1016/j.neulet.2004.06.025

Varnas, K., Halldin, C., Pike, V. W., and Hall, H. (2003). Distribution of 5-HT4 receptors in the postmortem human brain-an autoradiographic study using [125I]SB 207710. Eur. Neuropsychopharmacol. 13, 228-234. doi: 10.1016/S0924977X(03)00009-9

Wang, H., Chen, X. Y., Chen, W. F., Xue, Y., Wei, L., and Chen, L. (2013). Anticataleptic effects of 5-HT1B receptors in the globus pallidus. Neurosci. Res. 77, 162-169. doi: 10.1016/j.neures.2013.09.002

Wang, S., Zhang, Q. J., Liu, J., Wu, Z. H., Wang, T., Gui, Z. H., et al. (2009). Unilateral lesion of the nigrostriatal pathway induces an increase of neuronal firing of the midbrain raphe nuclei 5-HT neurons and a decrease of their response to 5-HT(1A) receptor stimulation in the rat. Neuroscience 159, 850-861. doi: 10.1016/j.neuroscience.2008.12.051

Wilms, K., Vierig, G., and Davidowa, H. (2001). Interactive effects of cholecystokinin-8S and various serotonin receptor agonists on the firing activity of neostriatal neuronesin rats. Neuropeptides 35, 257-270. doi: 10.1054/npep.2001.0875

Wong, E. H., Reynolds, G. P., Bonhaus, D. W., Hsu, S., and Eglen, R. M. (1996). Characterization of [3H]GR 113808 binding to 5-HT4 receptors in brain tissues from patients with neurodegenerative disorders. Behav. Brain Res. 73, 249-252. doi: 10.1016/0166-4328(96)00106-4

Xiang, Z., Wang, L., and Kitai, S. T. (2005). Modulation of spontaneous firing in rat subthalamic neurons by 5 -HT receptor subtypes. J. Neurophysiol. 93, 1145-1157. doi: 10.1152/jn.00561.2004

Yakel, J. L., Trussell, L. O., and Jackson, M. B. (1988). Three serotonin responses in cultured mouse hippocampal and striatal neurons. J. Neurosci. 8, 1273-1285.

Yamada, H., Aimi, Y., Nagatsu, I., Taki, K., Kudo, M., and Arai, R. (2007). Immunohistochemical detection of L-DOPA-derived dopamine within serotonergic fibers in the striatum and the substantia nigra pars reticulata in Parkinsonian model rats. Neurosci. Res. 59, 1-7. doi: 10.1016/j.neures.2007. 05.002

Zhang, Q. J., Gao, R., Liu, Y. P., and Wang, S. (2007a). Changes in the firing activity of serotonergic neurons in the dorsal raphe nucleus in a rat model of Parkinson's disease. Sheng Li Xue Bao 59, 183-189.

Zhang, X., Andren, P. E., and Svenningsson, P. (2007b). Changes on 5-HT(2) receptor mRNAs in striatum and subthalamic nucleus in Parkinson's disease model. Physiol. Behav. 92, 29-33. doi: 10.1016/j.physbeh.2007.05.033

Zhang, S. J., Wang, H., Xue, Y., Yung, W. H., and Chen, L. (2010). Behavioral and electrophysiological effects of 5-HT in globus pallidus of 6-hydroxydopamine lesioned rats. J. Neurosci. Res. 88, 1549-1556. doi: 10.1002/jnr. 22325

Zhang, X., Andren, P. E., Greengard, P., and Svenningsson, P. (2008). Evidence for a role of the 5-HT1B receptor and its adaptor protein, p11, in L-DOPA treatment of an animal model of Parkinsonism. Proc. Natl. Acad. Sci. U.S.A. 105, 2163-2168. doi: 10.1073/pnas.0711839105

Zhou, F. C., Bledsoe, S., and Murphy, J. (1991). Serotonergic sprouting is induced by dopamine-lesion in substantia nigra of adult rat brain. Brain Res. 556, 108-116. doi: 10.1016/0006-8993(91)90553-8

Conflict of Interest Statement: The authors declare that the research was conducted in the absence of any commercial or financial relationships that could be construed as a potential conflict of interest.

Received: 13 January 2014; accepted: 27 February 2014; published online: 17 March 2014.

Citation: Miguelez C, Morera-Herreras T, Torrecilla M, Ruiz-Ortega JA and Ugedo L (2014) Interaction between the 5-HT system and the basal ganglia: functional implication and therapeutic perspective in Parkinson's disease. Front. Neural Circuits 8:21. doi: $10.3389 /$ fncir.2014.00021

This article was submitted to the journal Frontiers in Neural Circuits.

Copyright (c) 2014 Miguelez, Morera-Herreras, Torrecilla, Ruiz-Ortega and Ugedo. This is an open-access article distributed under the terms of the Creative Commons Attribution License (CC BY). The use, distribution or reproduction in other forums is permitted, provided the original author(s) or licensor are credited and that the original publication in this journal is cited, in accordance with accepted academic practice. No use, distribution or reproduction is permitted which does not comply with these terms. 